\title{
Recognizing Student Activism. Analysing Practices in Recognizing Informal Learning in the EHEA
}

\author{
Marita Gasteiger and Janine Wulz
}

\section{Introduction}

The importance of recognition of non-formal and informal learning was first mentioned in the London Communiqué of 2007. The ministers of the EHEA countries agreed on the recognition of non-formal and informal learning as an "essential component of the EHEA, both internally and in a global context" (EHEA 2007, p. 3). The Communiqué supports the idea of informal learning achievements being relevant to the area of formal learning and commits to a broader understanding of learning and education in general.

However, policies enabling the recognition of informal learning in higher education have not been successfully implemented in all European countries yet (ESU 2018, p. 59). This paper aims to develop a better understanding of the implementation of policies and practices for recognition of informal learning in the EHEA. To gain insights into practices, challenges and barriers, the case of the recognition of informal learning from student activism within formal curricula was chosen as an example because of the already implemented practices and regulations in several countries.

This paper will, therefore, answer the questions of how informal learning is recognized in different EHEA countries, how student's activism is recognized as informal learning and what can be learned from the experiences of student's representatives for recognition of informal learning in general. The experiences of student's representatives are discussed (1) on national level as a source of information regarding the implemented policies and frameworks in their countries and (2) as a source for

\footnotetext{
M. Gasteiger ( $\square)$

University of Vienna, Vienna, Austria

e-mail: marita.gasteiger@gmx.at

J. Wulz

University of Victoria, Victoria, BC, Canada

e-mail:wulz@3s.co.at 
insights, experiences and practices within their institutions. Activism and engagement of students can be observed in multiple ways, taking place within formal representation and outside, involving various formats of self-organisation and protest. This paper is focussed on the specific experiences of student activists in representative roles, as in student unions or in higher education governance bodies.

The following chapters will discuss the recognition of informal learning in the EHEA, the understanding of student activism as informal learning and the results of a qualitative study undertaken in cooperation with national student unions. Two surveys - one on the system level and one on the institutional level-will provide insights in policies and practices of recognition in different countries as well as individual experiences of students' representatives. The paper will summarise identified best practices, barriers and challenges and will provide recommendations for the improvement of recognition practices in the EHEA.

\section{Informal Learning Policies in the EHEA}

The relevance of informal learning has been growing over the last two decades. It is closely linked to the changing world of learning and working. Learning is considered an ongoing, lifelong process, careers and jobs are changing over life and so do trainings, along with fast-changing technologies which require a steady learning process. However, learning cannot only be understood in relation to employability. Meeting social and environmental challenges at societal and individual level requires the development of new competences and, therefore, learning in diverse settings. Learning processes can start, proceed and conclude outside of formal institutions, through non-formal provision of learning, and also informally-as learning on a daily and unintended basis. ${ }^{1}$

The recognition of non-formal and informal learning achievements is on the European agenda for more than a decade, often linked to the recognition of prior learning, aiming for two main functions. First, making learning outcomes, competences and skills acquired in informal learning processes visible, transparent and comparable in- and outside the higher education systems. Second, broaden the access to higher education and enhance the mobility with the vocational sector and the labour market. Following these goals, the European Commission in 2001 articulated for the

\footnotetext{
${ }^{1}$ Based on Cedefop definitions of 2008, the terms of different forms of learning will be used as follows:

Formal learning "occurs in an organised and structured environment [...] and is explicitly designated as learning (in terms of objectives, time or resources). Formal learning is intentional from the learner's point of view. It typically leads to validation and certification (Cedefop 2008, p. 85).

Non-formal learning "is embedded in planned activities not explicitly designated as learning (in terms of learning objectives, learning time or learning support). Non-formal learning is intentional from the learner's point of view." (ibid., p. 133)

Informal learning is "resulting from daily activities related to work, family or leisure. It is not organised or structured in terms of objectives, time or learning support. Informal learning is in most cases unintentional from the learner's perspective." (ibid., p. 93).
} 
first time: "There is a clear need here for the formal sector to recognise and value non-formal and informal learning" (European Commission 2001, p. 4). Moreover, the development of proposals "on the identification, assessment and recognition of non-formal and informal learning as well as on the transfer and mutual recognition of formal certificates and diplomas" (ibid.) was formulated as a priority for action. In this light, the recognition of competences gained outside from formal learning is considered crucial for "building bridges between formal, non-formal and informal education" (Cedefop, 2019, p. 4). Creating links between formal, non-formal and informal learning environments is also considered a tool to "enhance access to education and training to a number of individuals that have acquired knowledge through formal, non-formal and informal learning but never had the chance to enrol in higher education" (ESU 2009, p. 126).

The relevance of recognition of informal and non-formal learning became vivid in the light of the increasing youth unemployment resulting from the economic crisis in 2008 hoping that "the validation of learning outcomes, namely knowledge, skills and competences acquired through non-formal and informal learning can play an important role in enhancing employability [...]" (Official Journal of the European Union 2012, p. 1). Moreover, the Bologna Working Group on Social Dimension and Lifelong Learning developed a "Strategy for the Development of the Social Dimension and Lifelong Learning in the European Higher Education Area to 2020", considering recognition of prior learning as an opportunity to broaden access to higher education and stating the objective to "work towards the development of flexible and transparent progression routes into higher education and the introduction of clear mechanisms for the recognition of prior learning based on a learning-outcomes approach for qualifications and the implementation of qualifications frameworks".

Already 2009, the Leuven Communiqué explicitly demanded "basic principles and procedures for recognition of prior learning on the basis of learning outcomes regardless of whether the knowledge, skills and competences were acquired through formal, non-formal or informal learning paths" (EHEA 2009, p. 3) to be included into national policies. Also, the Modernisation Agenda published in 2011 aims for developing

clear progression routes into higher education from vocational and other types of education, as well as mechanisms for recognising prior learning and experience gained outside formal education and training, especially by tackling challenges related to the implementation and use of national qualification frameworks linked to the European Qualification Framework. (Council of the European Union 2011, p. 7)

In 2012, the European Council recommended the member states to "have in place, no later than 2018 [...] arrangements for the validation of non-formal and informal learning" (Official Journal of the European Union 2012, p. 3), which was followed 2015 by the "European Guidelines for validating non-formal and informal learning" (Cedefop 2015) and the "European Inventory on validation of non-formal and informal learning", which states that "Member States are gradually placing validation of non-formal and informal learning higher on their policy agendas" (Cedefop 2016, p. 18f). 


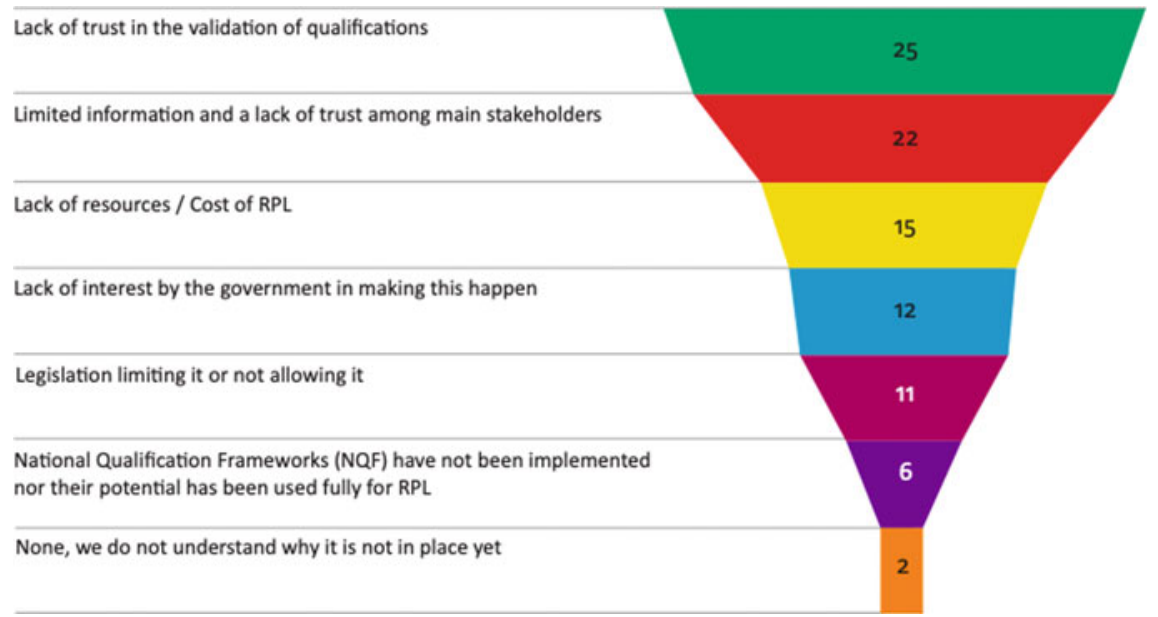

Fig. 1 Main barriers to recognition of prior learning (ESU 2018, p. 61)

Over the past years, the aim for recognition of prior learning, including informal learning, was reformulated various times in diverse policy documents. However, the results after one decade of initiatives are disenchanting. The Inventory in 2016 documented that the deadline in 2018 was not met (ibid.), and the European Students' Union (ESU) criticized in "Bologna with Student Eyes"

Only 63\% (27 out of 43) of the respondents reported having established procedures for recognition of prior learning or that such procedures are in a mature stage of development. This means, that such procedures are effectively non-existent in almost $40 \%$ of the higher education systems [...]. It is even more worrisome that according to the perspective of student unions, the situation has not changed at all since 2015 [...]. (ESU 2018, p. 59)

The European Students' Union identified several areas being challenging for the establishment of procedures for recognition of prior learning. The main concern is the lack of trust among institutions as well as stakeholders and the lack of established procedures for recognition, validation procedures. This is closely linked to the lack of trust in other organisations and institutions as well as lack of trust in validation procedures, if there are any established. One could argue, that the lack of trust is also deeply rooted in academic traditions and the lack of interest of established institutions as well as policy-makers to open up the academic ivory tower (Fig. 1).

\section{Learning from (Students ${ }^{6}$ ) Activism}

Engagement within social movements in general and specifically students' activism is broadly documented as a source of learning (see Biddix 2014; Harrison 2017; Kuh 1993; Quaye 2007; Rosas 2010; Schugurensky 2000). Informal learning from civic 
engagement and voluntary work is based on a high level of individual involvement in meaningful activities and results mainly from "doing". Given the diversity of activities, individual learning is diverse in its approaches and outcomes. Learning occurs by "applying oneself" in activities, by engaging in collective experience, thereby creating new knowledge, skills and competences (Hefler et al. 2017, p.57). Individuals become empowered actors through participation and gain influence over their social environment (Benedicto 2015).

Learning by participation is the most dominant form of informal learning in social movements or organisations, as the student movement. Informal learning occurs as a by-product when striving for the particular goals of the civic organisations, at individual as well as collective level. By reflective practices, learning can be made explicit and passed within social movement organisations allowing for horizontal social movement learning (Schugurensky et al. 2010). Learning in social movements is situated in the specific context and environment of a community; it is part of social interaction and the social world. Activists learn in spaces and places, in communities of practice in social processes through time and opportunities to observe and interact with others. Learning in social movements is a passionate and social process (Hefler et al. 2017, p.55).

Engagement in student movements can be considered being civic engagement, including both paid and unpaid forms of political activism (Michelsen et al. 2002). Research on learning from student activism can be found in diverse fields, including voluntary work, civic engagement and youth work as well as research on social movements. Student engagement has been proven to be a driver of social change for decades and, therefore, needs to be seen as a specific social movement as well. This can be observed in students' movements during the last decades as well as recent activism for environmental causes.

Student activism or student engagement in the context of this study is understood as the totality of activities carried out by students' representatives formally elected or appointed on behalf of the student union. This includes not only committee work, lobbying and counselling but also campaigning, protest measures and internal organizational work to the same extent. Student activism within student unions was chosen as an example because of a relative comparability of activities and learning achievements in student unions and the availability of research in learning from volunteering. Given the complex nature of learning in the students' movement as well as the diversity of competences acquired, the challenge of recognition has been met differently in several countries.

\section{Methodology}

This paper aims to answer the question of how recognition of student engagement as informal learning takes place in HEIs within the EHEA. It identifies best practices, challenges and lessons learnt in order to perform the recognition of informal learning in the EHEA in general. Questions of transparency in recognition of informal learning 
in student activism, the legal basis of recognition and ways of implementation as well as student representatives' experiences are discussed.

Analysis was undertaken based on two surveys in 11 countries in the EHEA. The first survey was undertaken in summer 2019 based on an online questionnaire and addressed student representatives at national level. The results of 11 national student unions were summarized in 11 country reports on legal conditions and practices of higher education institutions' recognition of informal learning of student activists. The countries participating in the first survey are Austria, Belgium (French community), Denmark, Estonia, Germany, Israel, Italy, Lithuania, Malta, Montenegro and Romania. These country reports provide an overview about different starting positions in the countries analysed, and enabled first insights in the range of approaches student representatives are facing.

A second survey was undertaken in summer 2019, aiming for responses from individual student representatives at institutional level, sharing their experiences on formalities, barriers and practicalities within implemented policies of recognition of prior learning in student activism. The online questionnaire was distributed among student unions in Europe, receiving answers from 80 students' representatives from Austria (4 answers), Denmark (3 answers), Estonia (1 answer), Germany (35 answers), Italy ( 2 answers), Montenegro (5 answers), Malta (1 answer), Poland (1 answer), Romania ( 25 answers) and Switzerland (1 answer). Two answers did not specify a country. Student representatives have backgrounds in medical and health studies (14 students), engineering and IT (19 students), social studies (15 students), cultural studies and philosophy (20 students), arts (5 students) and economics (4 students). Three students did not specify their field of study. The majority (65\%) of students is enrolled in a Bachelor programme, $25 \%$ students are enrolled in a Master programme, and $10 \%$ are in other programmes (e.g. law or diploma programmes). Most of the participants are involved in student activism for more than four years (36. $7 \%$ ) or two to three years $(29.1 \%)$. The share of those active for one to two years $(24.1 \%)$ or less than one year $(6.3 \%)$ is significantly lower in the survey.

Israel, Belgium and Lithuania participated at national level only (first survey), whereas Poland and Switzerland participated only at institutional level (second survey).

\section{Recognition of Student Engagement as Informal Learning in National Regulations and Policies}

This chapter presents the results of the survey based on the answers by 11 student unions at national level. One representative of the national student union (in most cases the president or the international officer of the union) participated in a qualitative survey, resulting in a brief country case study. Responses reflect mainly on already implemented policies, on the one hand, and legal constraints and opportunities, on the other hand. Within student unions, diverse people are involved in the 


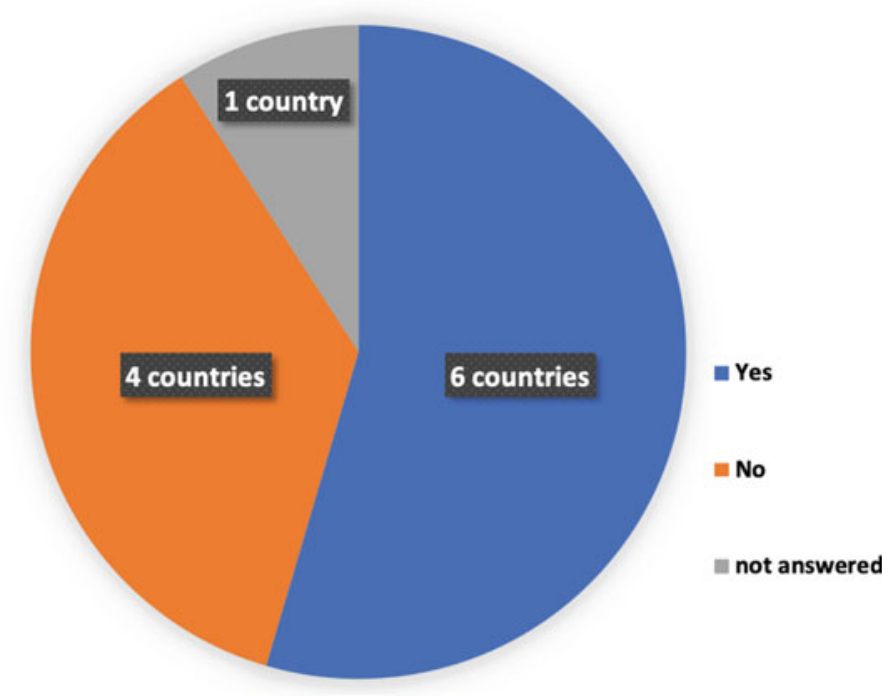

Fig. 2 Are there any legal regulations on recognition of informal learning in higher education at national level?

topic of recognition of informal learning, this includes presidencies and executive committees, international officers and specialists on policy or legal counselling.

\subsection{Legal Regulations and Policies on Recognition of Informal Learning on National Level}

The recognition of informal learning at national level is based on legal regulations in the majority of the countries (AT, BE (fr), DE, DK, LT, ME; see Fig. 2). This aligns with the result from "Bologna with Student Eyes", in 2018, where 63\% of all EHEA countries had established a mature procedure regarding recognition of prior learning. Four countries have not implemented legal regulations for recognition procedures of informal learning yet, despite the many public declarations at European and national level. However, having no legal regulations at national level does not necessarily result in no regulations at all, since there are regional or institutional regulations in place in some countries (Fig. 3).

Legal regulations, in theory, should go hand in hand with implemented policies. However, there are still four countries (EE, IL, IS, RO) participating in the survey which didn't implement policies regarding the recognition of informal learning yet. In some countries, this non-implementation is due to the division of responsibilities: 


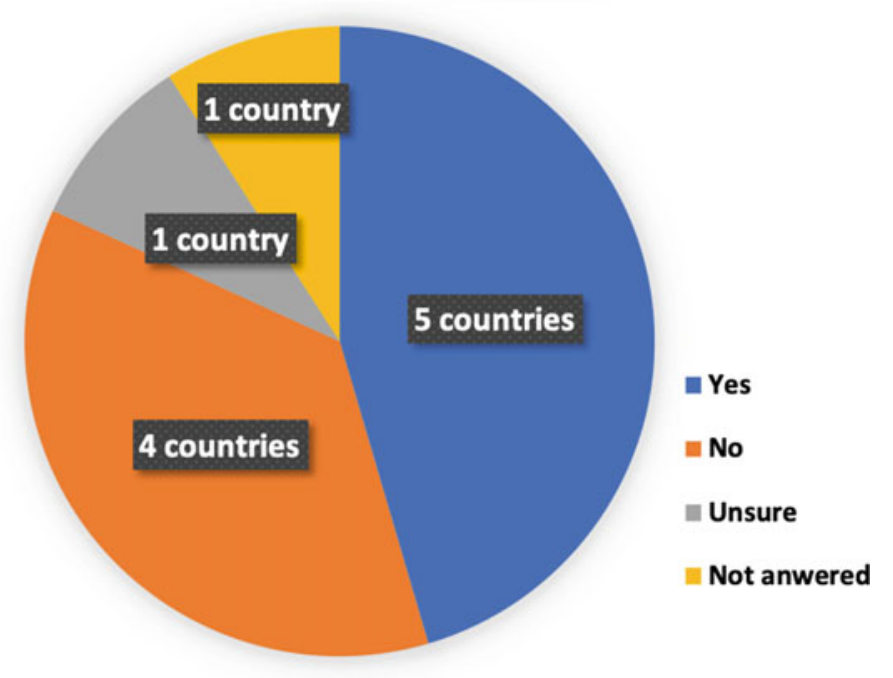

Fig. 3 Are there any policies on recognition of informal learning in higher education at national level?

Higher education and its legal basis is not a national responsibility but a regional one in some countries such as Germany, where regional Länder have autonomy in regulating educational policies. When the legal basis is missing completely, HEIs are dealing with the topic either on their own or not at all.

\subsection{Legal Regulations and Policies on Recognition of Informal Learning on University Level}

The poor legal situation at national level in several countries provides flexibility and opportunities for HEIs to recognize informal learning at the institutional level. At the same time, high flexibility leads to a diversity of procedures and diverse requirements for recognition or dimensions of what is recognized.

Legal regulations at university level include constitutions, statutes, standing orders or instructions. In many cases, national and institutional legislation go hand in hand: Whereas national (or regional) laws establish a general legal framework for recognition, institutions themselves decide about concrete procedures, involved resources and responsibilities within the university. Often, institutions are required to transpose and implement national policies within their strategic documents. This is represented in Fig. 4: 6 countries said earlier that there are legal regulations on the national level, 


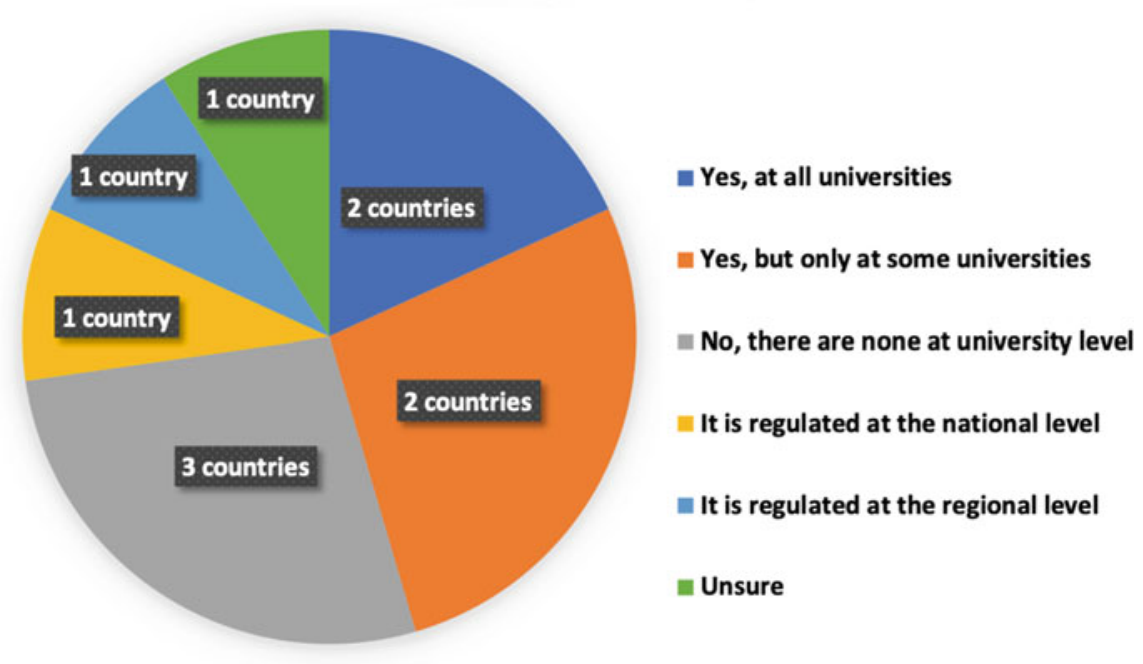

Fig. 4 Are there any legal regulations on recognition of informal learning at university level?

Belgium (fr), Denmark, Estonia, Israel and Lithuania answer that all or at least some universities have their own regulations. Nevertheless, in Malta, Romania and Italy no legal regulations are in place, and in other cases, recognition is regulated outside the institution at regional or national level (Austria, Germany), or there is a lack of clarity (Montenegro). Non-existing legal regulations on the national/regional and institutional levels often result in a lack of policies, leading to non-transparent procedures and uncertainty among the students' body (Fig. 5).

Countries where all or at least some universities have policies on recognition of informal learning are still the minority $(\mathbf{B E}(\mathbf{f r}), \mathbf{E T}, \mathbf{I L}, \mathbf{L T}, \mathbf{M T})$. In some cases, the topic seems to be regulated exclusively on the national or regional level (Germany) which makes it hard for HEIs to adapt procedures to their own conditions.

\subsection{Recognition of Student Activism as Informal Learning}

The recognition of student activism as informal learning based on transparent regulations is still not state of the art in most of the countries. In many cases it is based on individual cases or on informal regulations. Intransparency and incomprehensible decisions result in insecurity, student representatives are by their position and their responsibility of advocating for students exposed to possible arbitrariness. Especially this group needs to be capable to take up their position without being afraid that their requests of recognition might be rejected or delayed. A certain distance is, therefore, 


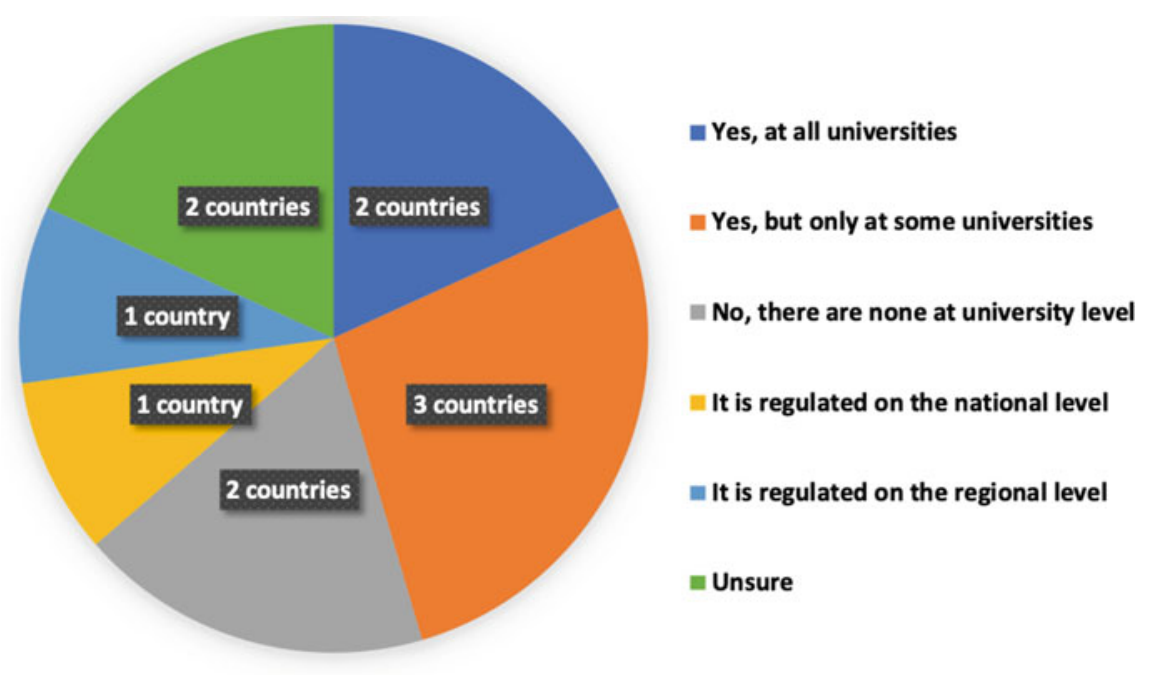

Fig. 5 Are there any policies on recognition of informal learning at university level?

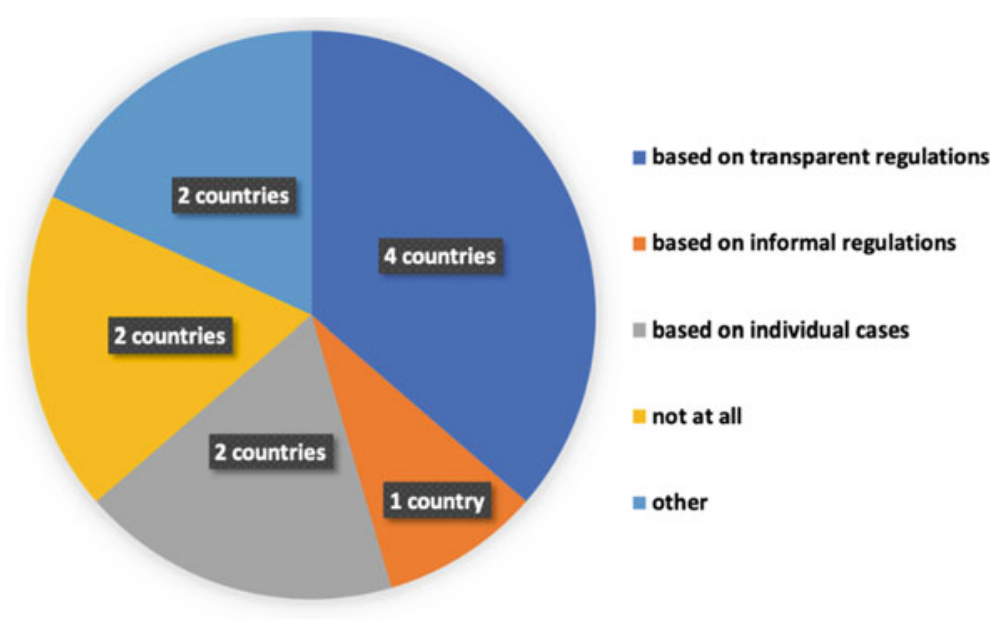

Fig. 6 Is student activism recognized?

needed if it comes to recognition of student activism. This can't be ensured as long as the procedure is founded on informal regulations or individual cases (Fig. 6).

Student activism as informal learning is recognised in different ways among countries and institutions. While countries like Austria, Germany, Denmark and Israel have legal regulations for recognition in place as in terms of providing a certain amount of ECTS, others do not recognise student activism at all (MT). Sometimes, 


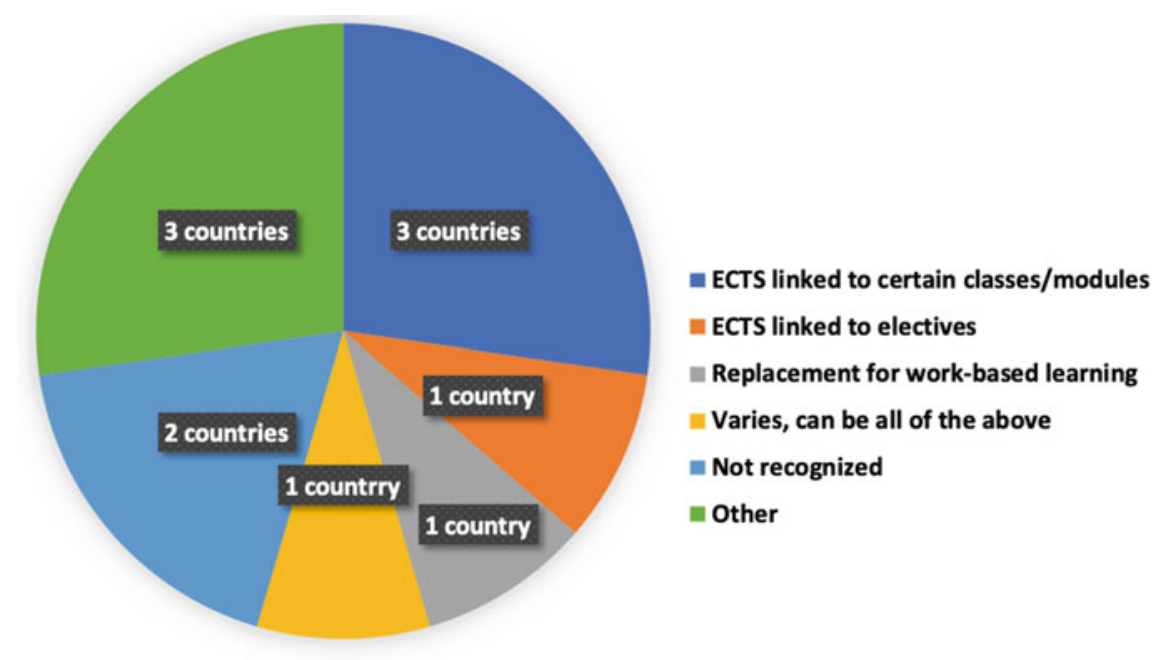

Fig. 7 In what way is student activism recognized in the curriculum?

for example in Belgium (fr) or Austria, the term "student activism" or "student representative" covers only a few positions within the student union (e.g. chair or member of the senate). Thus, the broad definition of student activism in this paper, as the totality of activities carried out by formally elected or appointed representatives, is not shared in all countries yet. The responsibility for providing evidence on the learning from activism is often directed to students-without guidance and transparency of what is expected. "It is difficult to prove what the student has learned from student activism," writes one respondent. Sometimes, activities need to be validated by a verification from the Students' Union. Out of the broad variety of practices on recognition of student activism, only a few of them can be considered transparent and adequate.

\subsection{Ways of Recognition of Student Activism}

Figure 7 shows that different approaches within the EHEA exist in order to provide opportunities for recognition of student activism.

Whereas in Austria, Israel and Lithuania ECTS acquired for student activism are linked to specific classes or modules in the curriculum, ECTS from student activism in Germany are usually linked to electives only. Thus, the recognition of ECTS depends on the availability of elective courses within the curriculum. In Italy, student activism can be recognized as replacement for work-based learning (e.g. 
mandatory internships). There is no recognition within the curriculum for student representatives in Montenegro, Belgium, Malta and Romania-but in Malta and Romania a remark appears on the transcript and Diploma Supplement.

In Estonia, several kinds of recognition are established, ECTS can be acquired from student activism and are recognized for work-based learning modules and specific classes in curricula. In Denmark, student activism can be recognised by replacing mandatory ECTS to be achieved within a certain time period. This is restricted to certain positions within the student union and other members of the national youth council. However, while activities reduce the student activists' mandatory workload, their work is not recognised for courses within the curriculum.

Countries and/or universities which enable the recognition of student for acquiring ECTS and linking them to the curriculum do often limit the use of ECTS to certain modules or electives only. This is the case in Germany, Austria, Israel, Lithuania and-as an exception - also in Romania. Also, in Estonia, students' representatives can only get a certain amount of ECTS through their activism. As there is no official or guaranteed recognition in Malta, Montenegro, Belgium and Italy, limitations are not a topic there.

\subsection{Student Unions and Their Role in the Recognition of Informal Learning and Student Activism}

Student unions are important stakeholders advocating for the recognition of informal learning. Most student unions at national level are involved in the question of recognition of informal learning at policy level. In countries with established regulations for recognition of informal learning (at institutional, regional or national level), the topic is considered less relevant in everyday business for student unions, as for example in Austria. In Estonia, mainly local student unions are dealing with recognition and in Montenegro, student union is currently striving for regulations and procedures regarding recognition of prior learning on the national and the institutional level (Fig. 8).

When it comes to student activism and its recognition, student unions engagement is more common. With the exception of Lithuania, Italy and Germany, all respondents are - at least rarely_-dealing with the topic of recognition of student activism. In Germany, the opportunities for the national student union to interfere are limited because of the regional responsibility of higher education (Fig. 9).

Activities taken up by student unions regarding the recognition of informal learning and recognition of student activism range from negotiations with the relevant authorities to support for local unions and activities such as campaigning and protesting: In Romania, Israel and Malta, student unions are involved in national policies (e.g. negotiating laws). In Denmark, they are active not only in national policy negotiations but also on the institutional level. In Montenegro, the student union is only involved at the university level. The Estonian student union provides education 


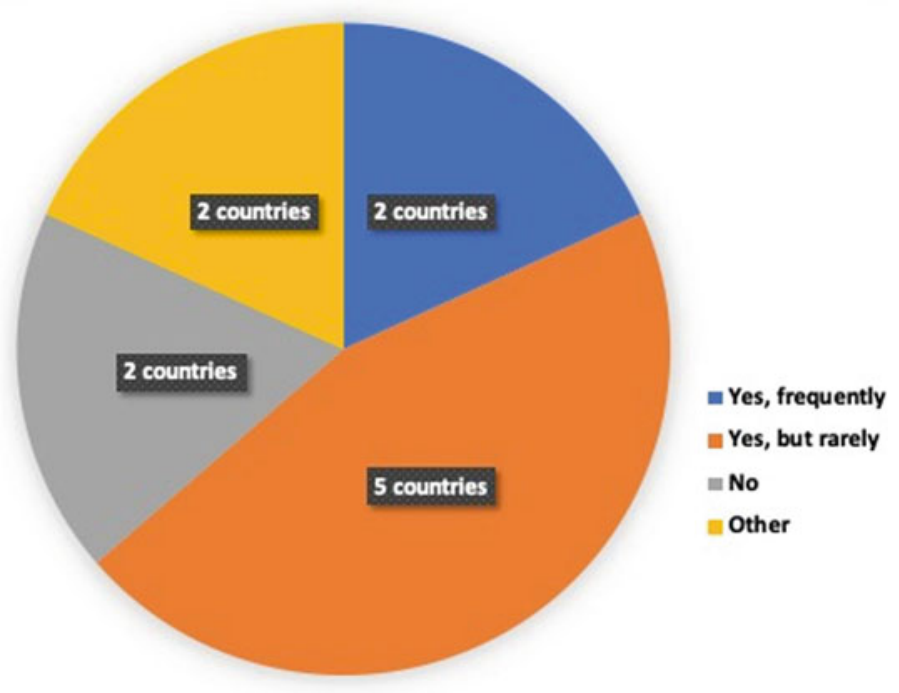

Fig. 8 Is recognition of informal learning an issue the student union is dealing with?

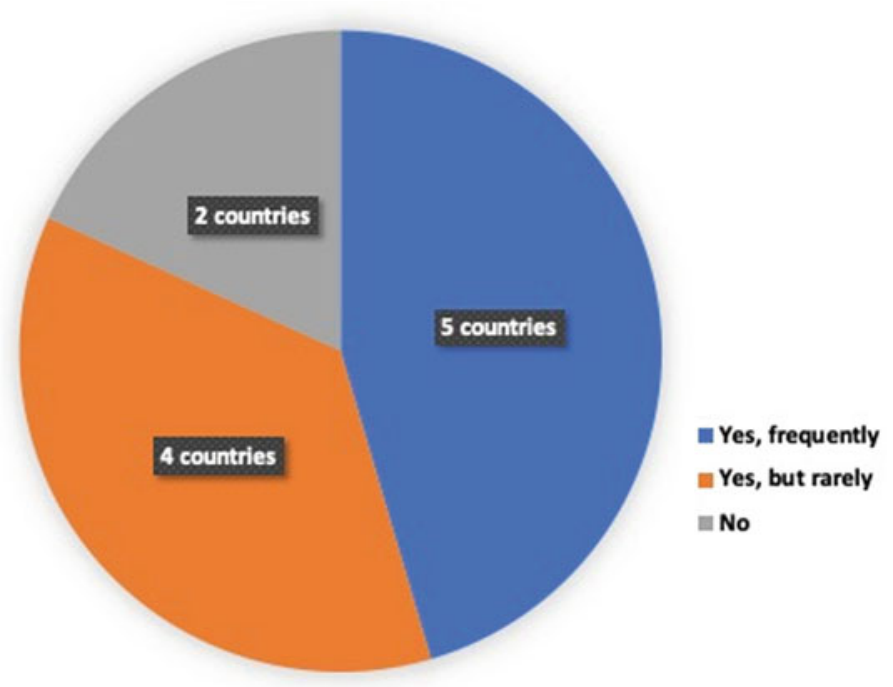

Fig. 9 Is the recognition of student activism an issue the student union is dealing with? 
and support for their local unions - as it was shown already earlier, they are dealing with the topic more on the institutional than on the national level. Legal support is provided by the Austrian student union, whereas in Belgium, direct activism and campaigning are more prevalent. Only in Germany, Italy and Lithuania, student unions are not performing any activities regarding recognition of informal learning or recognition of student activism.

\section{Practices and Insights from Local Students' Representatives}

This chapter presents the results of the survey filled in by local students' representatives at various institutions all over the EHEA. It shows barriers, challenges and best practices when it comes to procedures of recognition of student activism from a student perspective (Fig. 10).

\subsection{Recognition of Activism at the Institutional Level}

Regarding how student activism is recognized on the institutional level, the variety of answers is broad. The largest share got student activism recognized as replacement for work-based learning, followed by ECTS linked to a specific class or module. A smaller percentage got student activism recognized as ECTS linked to electives; some respondents stated to have activism recognized for more than one element (e.g. a seminar and a mandatory internship).

The collected data shows - as already on the national level-a broad variety of practices to recognize student activism: Respondents also listed mentioning of activism in the transcript as a way of recognition. Nevertheless, there is still one-fifth of the respondents who were not able to have their learning from activism recognized.

The number of representatives having experiences with recognition of activism at the institutional level nearly equals those not having dealt with it yet (Fig. 11). This does not necessarily mean that it is not possible for them-only that they don't have any experiences with the topic. "Other" includes answers besides an official recognition from the institution: At some HEIs, it is just not possible to get student activism recognized, in some cases student activism is connected to limited financial benefits like paying fewer student fees after a certain time of being active in the students' representation, or getting grants for a longer time-which is different from recognising student activism as (informal) learning. 


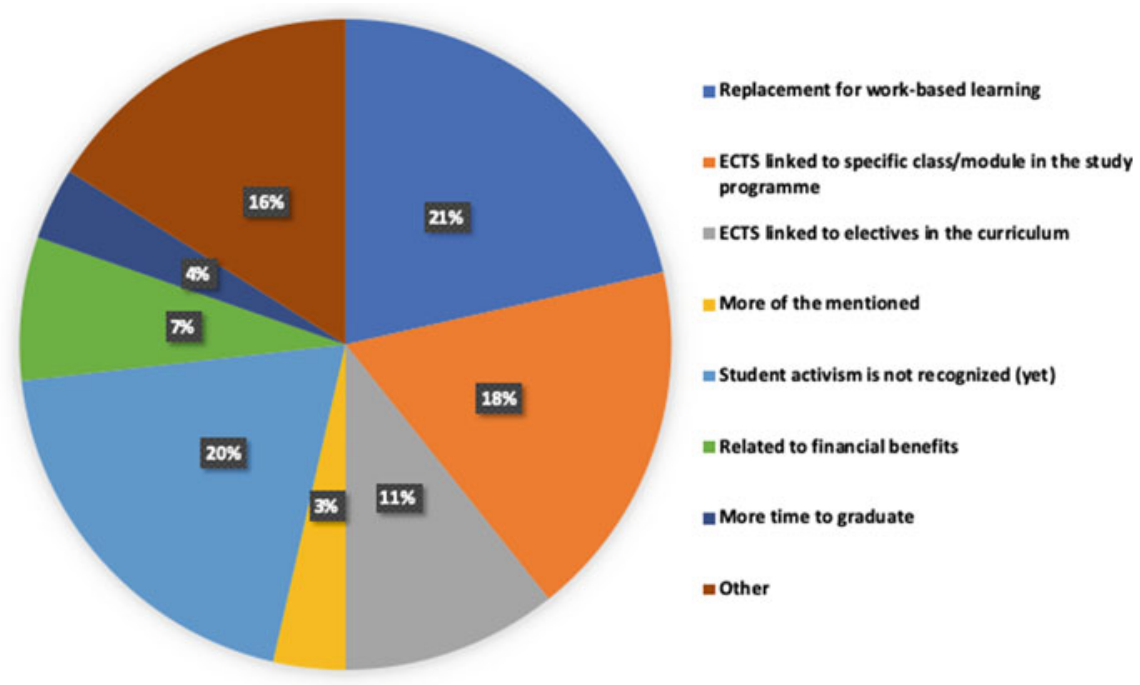

Fig. 10 What is/was your activism recognized for?

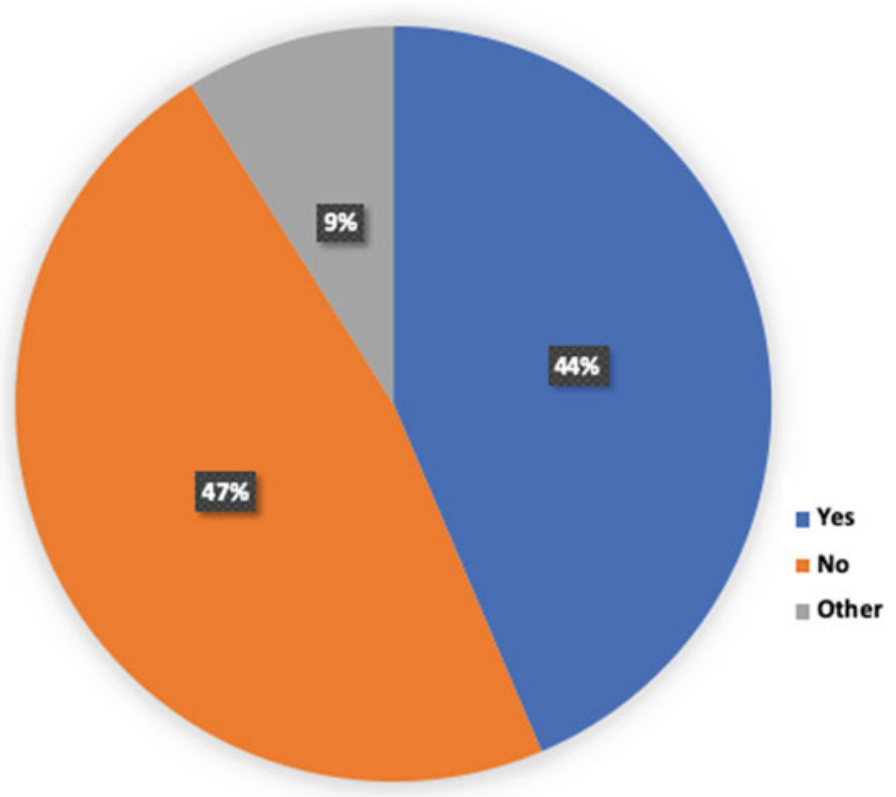

Fig. 11 Do you have experience with recognition of student activism? 


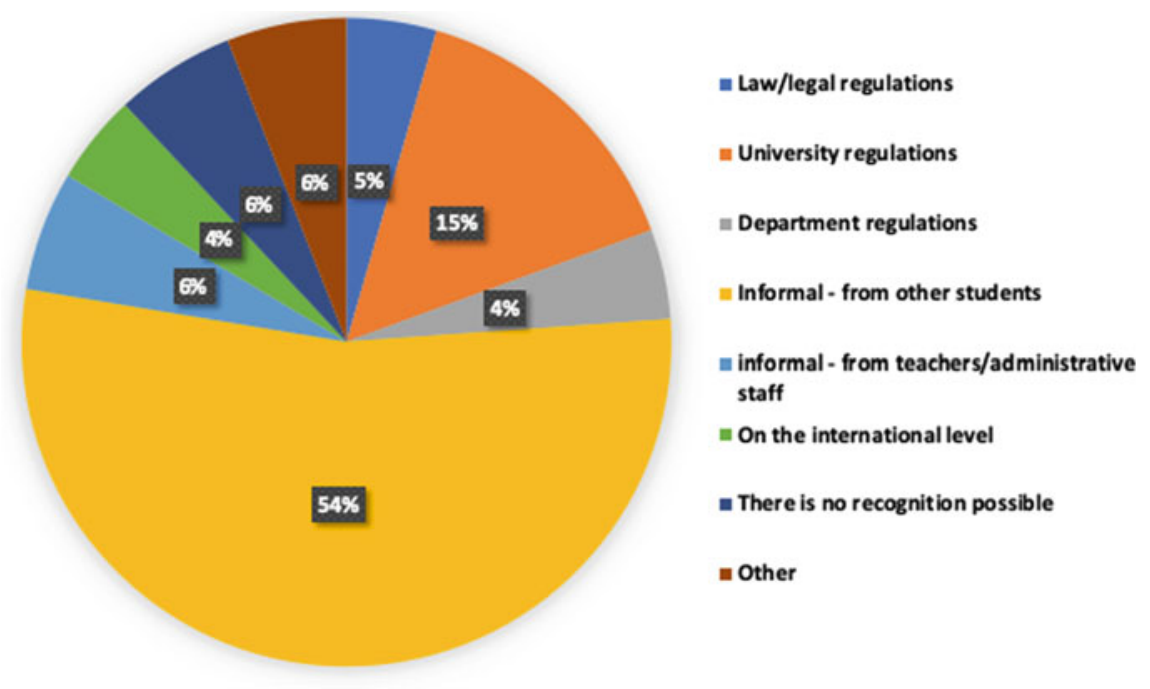

Fig. 12 How did you learn about opportunities for recognition?

\subsection{Information and Procedures at HEIs}

Students representatives describe a high level of uncertainty related to procedures and information about recognition of student activism or informal learning. The above figure shows the struggle for receiving reliable information on recognition procedures (Fig. 12).

$54 \%$ of the respondents gathered their knowledge from peers and colleagues in an informal way. Only $24 \%$ were able to retain information directly from the legal, university or department regulations. Informal information coming from peers or staff leads to legal uncertainty and intransparent procedures. However, in many cases, informal information is the only information available (Fig. 13).

The high extent of intransparency related to recognition is worrisome. The advocacy of student representatives is limited due to the lack of fundamental knowledge on existing procedures and criteria. Only $22 \%$ find information regarding recognition easy available at their institution. This is often related to a lack of existing regulation for the recognition of student activism. While surveys confirm that there is information on the implementation of procedures of recognition of national level (see 5.1), implementation at institutional level is even less (55\%). The transparency of information cannot be directly linked to the policies in place. Countries as Romania and Italy, lacking from national policies and legal frameworks, are considered at least partly transparent in their universities information towards students. Countries with legal regulations at national and university level, as for example Denmark, are only considered partly transparent, while Germany, with regulations at regional level, is 


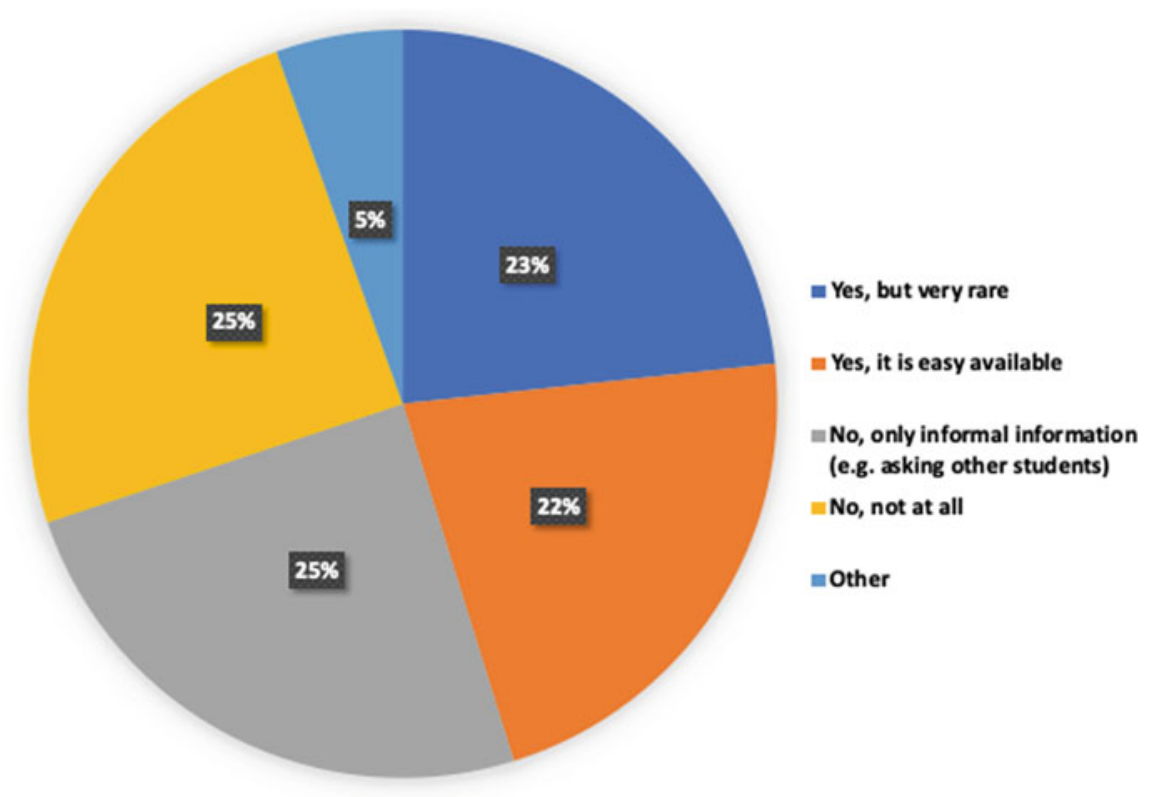

Fig. 13 Is there information on recognition available(e.g. information on ways of recognition, previous decisions)?

considered very diverse by students, as some report easy to find policies while others lack from information.

Procedures of recognition of student activities are diverse. In many cases, students' representatives apply for recognition using a standardised form at the beginning of their engagement or at the end of the semester. In some cases, reports or confirmations from the student union for their activities or projects are required. Formal procedures leading to recognition within the curriculum have similar structures among countries.

A formal request for recognition has to be issued by the national student or the local student union. Documents required include confirmations from the local student union, activity reports, certificates or proof of accomplished projects. These documents are checked by the responsible unit at the institution, and a decision is taken. Positive decisions directly lead to official recognition, ranging from certification of confirmation engagement, position or activities to recognition in the form of ECTS. The decision is mostly taken by individual staff members in an administrative position, this could be at departmental or faculty level; in some cases the study coordinator or the admission office are in charge. In one case, a committee consisting of teachers and other students' representatives discussing and evaluating the request for recognition is described. Figure 15 doesn't include the most common informal procedures of recognition. Students' representatives are not only dependent on informal information coming from administrative staff (i.e. not publicly accessible or even 


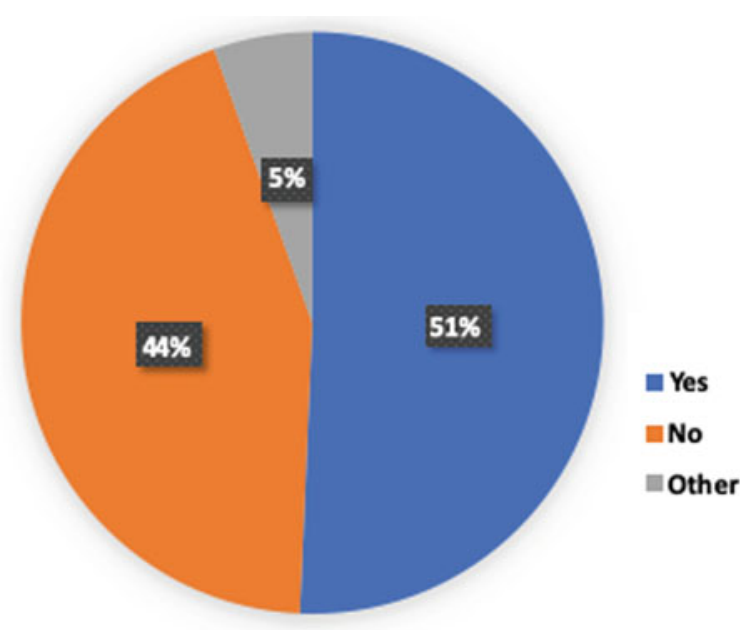

Fig. 14 Is there a specific procedure for recognition of student activism? (e.g. forms, timelines, signatures,...)

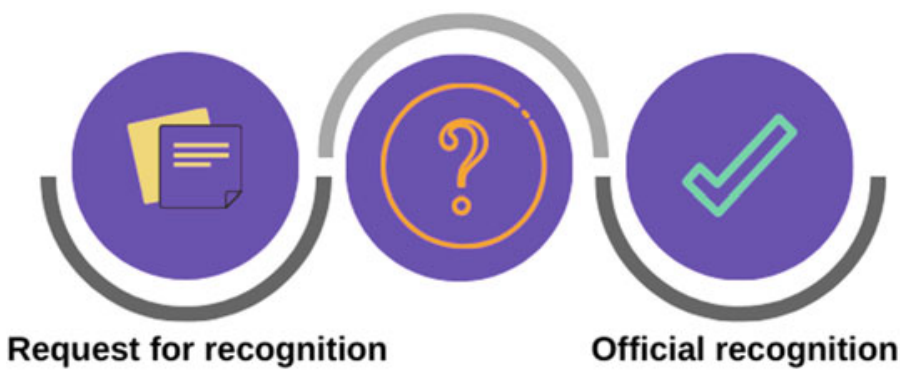

Fig. 15 Decision about recognition

not written information) but also on decision-making procedures carried out by one individual.

\subsection{Experiences with Recognition Procedures}

Despite the diversity and intransparency of procedures, a majority of students considers their attempts for recognizing their learning from student activism as informal learning successful. Nevertheless, one-third of the respondents was not successful in 
Fig. 16 Have your attempts for recognition of student activism been successful?

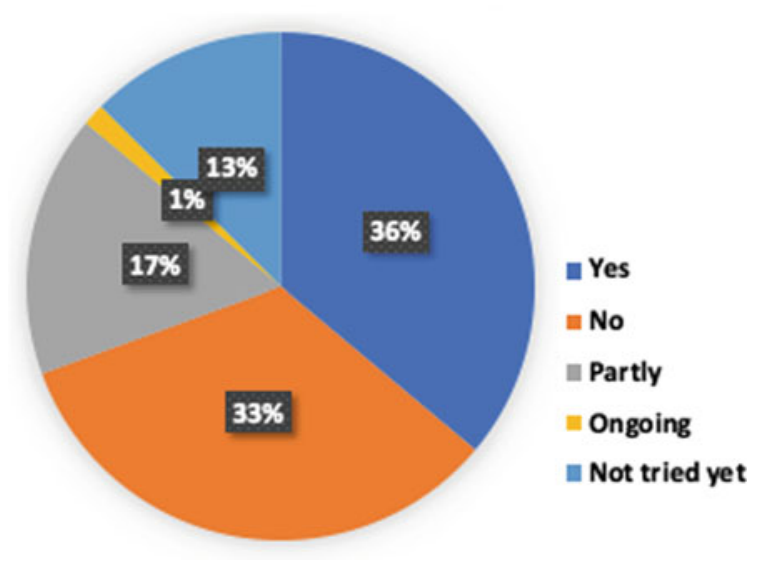

their attempts. Personal impressions from students' representatives collected in this survey show concerns of their institution not wanting them to get student activism recognized: "The university is very strict on this thing (they don't really want us to have more credits for volunteering) and no local organisation on my university could get past the requests they made."

Survey results suggest differences among countries in how successful attempts for recognition of students' activism are. In Romania, 18 (out of 22 attempts) were successful, and in Austria, 3 out of 4 students report successful recognition procedures. In Germany, half of the students (14 out of 31 attempts) were not successful in recognizing their activism. For other countries, the numbers of respondents are too low to consider trends (Fig. 16).

Further personal impressions point out that possibilities to get student activism recognized are very important to students' representatives who cannot do it yet due to missing procedures and regulations (Fig. 14). The procedure of recognition is described as positive only by $14 \%$ of the respondents, as easy by $20 \%$, whereas nearly half of them claim it to be negative, complicated or stressful (Fig. 17).

Further personal experiences and insights from students' representatives show the bureaucracy of the process is an issue for students' representatives as well as their dependency on the responsible unit from the university. Some of them also mention that the recognition doesn't reflect the real workload done within the students' representation. Also, strict deadlines, long waiting times and complex processes were mentioned as challenging.

In general, about half of the student representatives who attempted to achieve recognition for their student activism were successful. Successful cases were reported from Austria, Germany, Italy, Malta, Romania and Switzerland, while negative experiences were reported from Germany, Italy, Estonia, Montenegro and Romania. Partial achievements were experienced in Romania and Germany. Due to low 


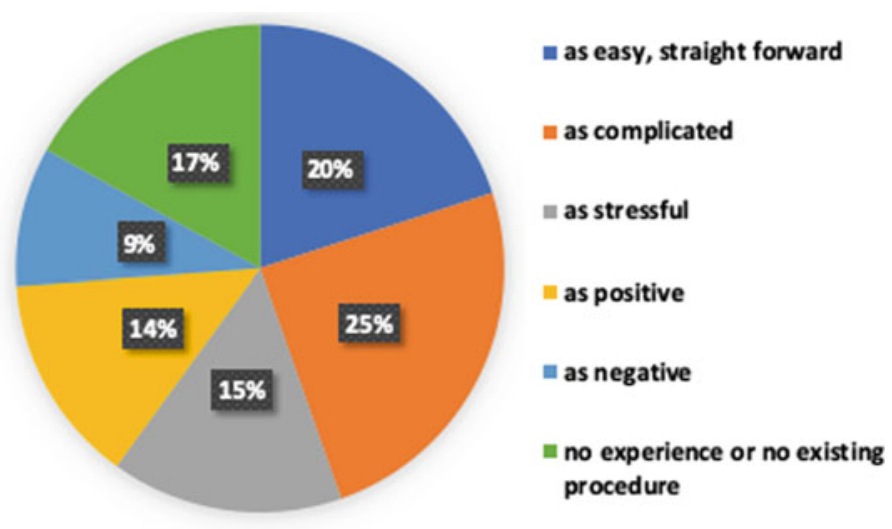

Fig. 17 Would you describe the procedure of recognition ...

numbers of respondents in some countries, there can only be a trend suggested. This trend concludes that attempts for recognition of student activism are only partly linked to policies and legal regulations in place. Countries with legal regulations and policies in place (Germany, Austria, Malta) have high numbers of at least partial recognition of students' activism. However, there are also cases of recognition in countries without legal frameworks and policies in place, as Italy and Romania. The high percentage of (partly) successful attempts (16 out of 20 in Romania) could be explained since student activism is neither recognised in the curriculum nor in the acquisition of ECTS but in a remark in the diploma supplement only.

\section{Conclusions and Findings}

Within this paper, the recognition of representative student activism as informal learning in higher education is studied. Results draw on two qualitative surveys, conducted 2019 in 11 countries among student unions and individual student activists.

Three steps of recognition of student activism as informal learning can be identified from this survey. Successful attempts of recognition of student activism depend on the policies and frameworks in place to support these steps.

In a first step, a formal request is issued by a student, usually by providing documentation or proof for their student activism. The procedures of recognition are often intransparent for students, only about one-fourth of students found information provided by universities, while more than half of the students rely on (informal) information provided by their peers. The transparency of information accessible for 
students cannot be directly linked to the policies and regulations on recognition of student's activism in place at national or university level.

The second step is made by a decision-making body at the university. These bodies differ a lot among institutions. They can include one or more people, however, student representatives are rarely mentioned as being involved in this process. This results in processes that are often informal and regulated on a case by case basis by individual members of faculty or administration, especially when it comes to recognition of informal learning within specific courses (e.g. classes involving working experiences or internships). About half of the students reports on procedures for decision-making in place at their institution. A country analysis suggests that procedures are more likely to be in place in countries with national frameworks and university policies, however there are cases to be excluded (e.g. Romania) from this trend.

The third step is the proceeding from decision to official recognition. This is where ECTS points are linked to specific elements of the curriculum, or the participation in student activism is mentioned in the Diploma Supplement. About half of the students reports successful experiences with recognition of their activism. A trend suggests that countries with policies and legal frameworks in place do have higher rates of success of recognizing students activism; however, it seems that this cannot be generalized amongst regions (especially in Germany) and institutions.

The main findings of this study can be summarized in the following way: The legal basis for recognition of student activism as informal learning is highly diverse among countries. Countries do have regulations at national and institutional level (Belgium (fr), Denmark, Lithuania), only at national level (Austria, Germany, Montenegro) or only at university level (Estonia, Israel). No regulations could be found in Romania, Malta and Italy. However, the regulations and policies in place do not necessarily reflect their transparency towards students and the accessibility of recognition procedures. Overall, the diversity of regulations and procedures are hard to overlook for students. Experiences from individual representative student activists range from smooth and transparent procedures to informal and hardly understandable processes. Often, students depend on informal networks, as other students or administrative personnel, to receive information related to application procedures and decision-making. This results in negative experiences, understanding the recognition of informal learning as complicated and stressful processes. Also, students express their impression of institutional lack of interest in recognizing student activism as informal learning. Student unions in most countries are working at national and institutional level to negotiate legal frameworks and policies for recognition within formal meetings as well as in protest and activism and providing information on procedures. 


\section{Recommendations}

The following recommendations are based on the feedback from national student unions, on the one hand, and on personal experiences from students' representatives within their institutions, on the other hand.

On the national level, legal regulations-as committed by the responsible ministers - need to be implemented in all EHEA countries. Non-existing regulations result in legal uncertainty and incomprehensible procedures for students' representatives. Student activism needs to be received not only as a learning process but also as an important contribution to higher education in general and to the specific institution in particular. The survey results shout out for the development of national policies and legal regulations. While representative student activism is a relatively clear field of activity to be recognized, informal learning and engagement involve an extensive diversity of learning outcomes to be recognised as informal learning. National policies and regulations need to take this diversity into account and ensure procedures to be embedded at institutional level that are transparent and reliable. It is recommended to develop these regulations in the light of the National Qualifications Framework, but also in relation to quality assurance policies. The European Framework for Quality Assurance in Higher Education could be used as a starting point for these developments.

The survey shows highly diverse and often in transparent procedures at institutional levels, resulting in negative experiences with recognition of informal learning. Thus, recommendations for institutions focus on the development of transparent and reliable procedures for the recognition of informal learning. This includes the development of institutional policies as well as the training of staff and academics involved in the process of recognition. Already existing procedures might be evaluated and improved together with staff and students' representatives in order to provide more reliable and less stressful or complicated procedures. Moreover, exchange of best practices and collaboration among universities and departments of the same field at regional and national level are highly recommended to avoid inter-institutional conflicts. Additionally, a transparent information system on recognition of informal learning is recommended at institutional level. This should include representative student activism, as well as other forms of student engagement and ideally be linked to policies of recognition of prior learning. Information needs to be understandable and accessible, including counselling for understanding complex matters of recognition. The process of request should be simplified and unified within the institutions, making use of existing tools for making learning outcomes and gained competences visible and comparable, such as the youth pass in youth work. Not only the decision-making process but also the decision must be transparent and understandable, including timely and written decisions and a structured process of appeal. Student representatives should be involved in the development of these institutional regulations and its execution.

Student representatives themselves need to continue (or in some cases: to start) their engagement in the field of recognition, not only aiming for better recognition 
of their own activism recognized but also to open student activism for underrepresented groups: As student activism is hardly ever paid, only students with a strong social-economic background can afford to get involved over the years; Recognition of activism within the curriculum would enable new groups to partake. Students and student unions are valuable sources for gaining information on recognition procedures to be used in cooperation with the institution. However, the responsibility to implement transparent, reliable and quick legislation and policies belongs to legislators and institutions.

The example of recognizing student activism makes the lack of regulations and transparency for recognition of informal learning in many countries and institutions visible. While policies at European level take a clear stand in favour of the recognition of prior learning for decades, policy implementation at national and institutional level still have a way to go. However, stakeholders in many countries are aware of their responsibility towards transparent and fair recognition of informal learning and have started to develop perspectives and policies, which could be used as a starting point for an enhanced dialogue at European and national level.

\section{References}

Benedicto, Jorge (2015). Youth participation as meaningful citizenship experience: a challenge to improve democratic life. In: Commission, European (ed.). Youth work and non-formal learning in Europe's education landscape. A quarter of a century of EU cooperation for youth policy and practice. Luxembourg: Publications Office of the European Union.

Biddix, J. P. (2014). Development through dissent: Campus activism and civic learning. Radical academia"? Understanding the climates for campus activists C. J. B. G. Martin. San Francisco, CA, Jossey-Bass.

Cedefop (2008). Terminology of European education and training policy. A selection of 100 key terms. Online: https://www.cedefop.europa.eu/files/4064_en.pdf

Cedefop (2015). European guidelines for validating non-formal and informal learning. Luxembourg: Publications Office. Cedefop reference series; No 104.

Cedefop (2016). European Inventory on validation of non-formal and informal learning 2016 Update. Executive Summary. Online: https://www.cedefop.europa.eu/files/executive_ summary-_validation_inventory_2016_0.pdf

Council of the European Union (2011). Council conclusions on the modernisation of higher education. 3128th EDUCATION, YOUTH, CULTURE and SPORT Council meeting Brussels, 28 and 29 November 2011. Online: https://www.consilium.europa.eu/uedocs/cms_data/docs/pressdata/ en/educ/126375.pdf

EHEA (2007). London Communiqué. Towards the European Higher Education Area: responding to challenges in a globalised world. Online: http://www.ehea.info/Upload/document/ministerial_ declarations/2007_London_Communique_English_588697.pdf

EHEA (2009). The Bologna Process 2020 - The European Higher Education Area in the new decade. Online: http://www.ehea.info/media.ehea.info/file/2009_Leuven_Louvain-laNeuve/06/1/Leuven_Louvain-la-Neuve_Communique_April_2009_595061.pdf

ESU (2009). Bologna with Student Eyes 2009. Online: http://www.ehea.info/media.ehea.info/file/ ESU/28/4/Bologna-With-Student-Eyes_2009_565284.pdf

ESU (2018). Bologna with Student Eyes 2018. The Final Countdown. Online: http://www.ehea. info/media.ehea.info/file/2018_Paris/06/0/BWSE-2018_web_lowres_952060.pdf 
European Commission (2001). Making a European Area of Lifelong Learning. Online: http://aei. pitt.edu/42878/1/com2001_0678.pdf

Harrison, L. M., \& Mather, P. C. (2017). Making Meaning of Student Activism: Student Activist and Administrator Perspectives. Mid-Western Educational Researcher, 29(2). 117-135

Hefler, G., Steinheimer, E., \& Wulz, J. (2017). Literature Review on Initiatives to Improve Early Career Conditions Across EU Member States (Deliverable 7.2). H2020. ENLIVEN.

Kuh, George D. (1993). In Their Own Words: What Students Learn outside the Classroom. American Educational Research Journal, 30(2 Summer), 277-304.

Michelsen, E., Zaff, J. F., \& Hair, E. C. (2002). Civic engagement programs and youth development: A synthesis. Washington: Child Trends.

Official Journal of the European Union (2012). Council Recommendation of 20 December 2012 on the validation of non-formal and informal learning. Online: https://eur-lex.europa.eu/LexUriServ/ LexUriServ.do?uri=OJ:C:2012:398:0001:0005:EN:PDF

Quaye, S. J. (2007). The Outcomes of Contemporary Student Activism. About Campus, 12(2), 2-9.

Rosas, M. (2010). College student activism: an exploration of learning outcomes.Thesis. University of Iowa.

Schugurensky, D. (2000). The forms of informal learning: Towards a conceptualization of the field. Ontario: Centre for the Study of Education and Work.

Schugurensky, D., Dauguid, F., \& Mündel, K. (2010). Volunteer work and informal learning. Exploring the connections. In Livingstone, David W. (Ed.), Exploring the connections. Routledge.

Open Access This chapter is licensed under the terms of the Creative Commons Attribution 4.0 International License (http://creativecommons.org/licenses/by/4.0/), which permits use, sharing, adaptation, distribution and reproduction in any medium or format, as long as you give appropriate credit to the original author(s) and the source, provide a link to the Creative Commons license and indicate if changes were made.

The images or other third party material in this chapter are included in the chapter's Creative Commons license, unless indicated otherwise in a credit line to the material. If material is not included in the chapter's Creative Commons license and your intended use is not permitted by statutory regulation or exceeds the permitted use, you will need to obtain permission directly from the copyright holder.

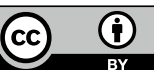

